\title{
Organisational support and safety
} management in shipping: A Study of shipboard safety supervision

\author{
Xue, C
}

http://hdl.handle.net/10026.1/14601

\subsection{7/1035304619869575}

The Economic and Labour Relations Review

SAGE Publications

All content in PEARL is protected by copyright law. Author manuscripts are made available in accordance with publisher policies. Please cite only the published version using the details provided on the item record or document. In the absence of an open licence (e.g. Creative Commons), permissions for further reuse of content should be sought from the publisher or author. 


\title{
Organisational support and safety management in shipping: A study of shipboard safety supervision ${ }^{1}$
}

\author{
Conghua Xue (Conghua_xue@hotmail.com) \\ Department of Humanities and Arts, Nantong Shipping College, Jiangsu, China \\ Lijun Tang (Lijun.tang@plymouth.ac.uk) \\ School of Business, Plymouth University, United Kingdom
}

\begin{abstract}
This article examines how ship managers make use of the opportunities of ship visits to provide shipboard employees with support and monitor the implementation of shipboard safety management. Semi-structured interviews were conducted with both managers from company offices and crew members on ships. The interviewees from both parties saw that the main purpose of ship visits was for ship inspection. During the visits, the managers focused on enforcing safety compliance with surveillance and punishment. From the perspective of crew members, because the managers only visited ships occasionally, they were unlikely to have sound knowledge of the specific situations and work routines on their ships. Consequently the managers' interventions for safety compliance served to interrupt the work plans of crew members and led to extra workload, psychological pressure and fatigue, which was the very antithesis to safety management.
\end{abstract}

Key words: Organisational support, Safety management, Safety supervision, ISM Code, Case Study, Shipping industry

\footnotetext{
1 To be published in The Economic and Labour Relations Review.
} 


\section{Introduction}

Shipping is a safety critical industry where operational errors may lead to maritime accidents with consequences of property damage, loss of lives and environmental pollution. Against this background, and spurred by a few high profile sea accidents, particularly the tragic loss of the Herald of Free Enterprise, the International Maritime Organisation (IMO) adopted the International Safety Management (ISM) Code, which came into full force in 2002 worldwide. The Code is designed to promote selfregulation in shipping by making ship managers assume the responsibility for ensuring that workplace health and safety in their individual organisations is effectively managed (Bhattacharya 2009; Walters and Bailey 2013). It provides a broad framework of safety management principles, based on which ship managers should design and adopt safety management systems (SMSs) that are tailored to their individual circumstances and risk profiles (Bhattacharya 2009; Walters and Bailey 2013). According to the Code, the managers should identify and assess health and safety hazards associated with their ship operations, put in place effective measures to eliminate, reduce or control risks, and periodically audit and review their SMSs. The Code further requires shore-based management to provide shipboard employees with sufficient support and resources, engage them in actively participating in shipboard safety management, and facilitate their upwards communication of safety deficiencies and concerns with the managers.

Despite ISM implementation, under-reporting of safety deficiencies and incidents is common in the industry (Ellis et al. 2010; Hassel et al., 2011, Luo and Shin 2019; Psarros et al., 2010). Unsurprisingly a considerable amount of research attention on 
ISM implementation has been given to the practice of incident reporting on ships, and the findings suggest that seafarers are reluctant to report any incident for fear that they might get blamed (Bhattacharya 2011; 2012; Lappalainen et al. 2011; Oltedal and McArthur 2011; Xue et al. 2018; 2019). The issue of 'direct' management support and supervision of shipboard safety management during managers' ship visits and its impact on safety management, however, is under-studied. Drawing on organisational support theory (Eisenberger et al. 1986; Eisenberger et al. 2016; Kurtessis et al. 2017), the article examines this issue.

From the social exchange perspective, organisational support theory (in the context of safety management) proposes that when employees believe that the organisation cares about and puts resources to improve their safety and well-being, they feel obliged to adopt safety behaviour and show safety commitment (Hofmann and Morgeson 1999; Mearns and Reader, 2008). This theory implies positive and reciprocal exchange and interaction between managers and employees. In the shipping industry, interaction between shore-based management and seafarers is mostly mediated by information and communication technology (ICT), such as satellite communication, due to the physical separation between shore-based management and shipboard workplace. Nevertheless, face-to-face interaction is highlighted when shore-based management visit their ships occasionally. Ship visits provide ship managers and superintendents a good opportunity to observe real situations on ships, provide guidance and support accordingly, and show their considerations for crew members and safety at workplace. As such, they can be seen as critical moments for shore-ship exchange. This article focuses on these hitherto 
unexamined moments, examining shore-ship exchange in these moments and exploring its safety implications for ISM implementation. As this particular focus provides a unique perspective to examine ISM implementation, it makes a fresh contribution to the understanding of safety management in shipping.

\section{Organisational support and its engagement with safety management}

Built on social exchange theory (Blau 1964; Gouldner 1960; Levinson 1965), Eisenberger et al. (1986) developed organisational support theory (OST) to investigate and explain engagement of employees in organizations. According to this theory, when employees believe that the organisation values their contributions and cares about their well-being which is defined as Perceived Organisational Support (POS), they feel obliged to respond in kind and repay the organisation. For example, they may increase work effort and affective commitment to the organisation, improve organisational citizenship behaviours, and trust that improved performance would be rewarded (Eisenberger et al. 1986; Eisenberger et al. 2016; Kurtessis et al. 2017; O’Donnell et al. 2012).

OST is developed in a general organisational context and explains socioeconomical reciprocal exchange between employees and managers in organisations. In safety studies, similarly, employee and manager exchange and interaction is regarded to be important for safety behaviours and outcomes (Bhattacharya and Tang 2013a; Clarke and Ward 2006; Xue et al. 2018; Zohar 2010). In this context, Hofmann and 
Morgeson (1999) applied OST to examine the links between leader-member exchange, POS, and safety management issues in manufacturing plants. The findings indicated that both leader-member exchange and POS encouraged employees to engage in safety related communication which in turn increased employee safety commitment. Their research further indicated that as a result of increased safety communication and commitment, accidents at workplace decreased. Similarly, Mearns and Reader (2008) conducted a survey in the UK offshore oil and gas industry and found that POS (in the form of positive perceptions of organisational, supervisor and workmate support for health) led to reciprocal safety behaviours by employees. Such safety behaviours included monitoring the safety behaviours of colleagues, correcting safety deficiencies, and informing management about safety problems, near misses and incidents.

In industrial safety studies, a distinction has been made between the safe person approach and the safe place approach. The safe person approach places significant emphasis on employee behaviour and attitude, focuses on training and strict supervision, and aims to identify weaknesses of individual workers as primary causes of accidents (Frick and Wren, 2000; Gunningham and Jonestone, 2000; Reason 2000; Wokutch and VanSandt, 2000). Instead of targeting and blaming individuals, the safe place approach starts from the premise that humans are fallible and that human errors are to be expected. It focusses on the conditions under which individuals work and stresses the importance of creating a safe working environment where employers provide sufficient resources to build up defences to prevent errors or mitigate their 
effects (Bhattacharya 2009; Frick and Wren 2000; Gunningham and Jonestone 2000; Reason 2000; Wokutch and VanSandt 2000).

The safe place approach also relies on interaction between employees and managers. In this approach, employers demonstrate their commitment to safety by providing adequate resources and encourage employees to actively participate in safety management. As employees have an intimate knowledge of workplace and its potential hazards, their participation, such as promoting the safety program within the workplace, demonstrating initiatives, correcting safety deficiencies, and communicating to management about safety problems (Inness et al. 2010; Neal et al. 2000), is essential for workplace safety (Gunningham 2008). According to Hofmann and Morgeson (1999) and Mearns and Reader (2008) as discussed above, employees' active participation is driven by POS and positive leader-member exchange. Thus, it can be said that POS and reciprocal exchange between employee and manager is an integral element in the safe place approach.

In the shipping industry, the ISM Code requires commitment from the top management and stipulates that the management should provide adequate resources and support to safeguard shipboard safety. It also requires shipping companies to put procedures in place which enable seafarers to participate in identifying, assessing and mitigating risks and report safety deficiencies and problems. As such, the Code in theory promotes a safe place approach. ISM implementation has attracted considerable amount of research attention since its adoption in the late 1990s. Studies taking quantitative approaches in general suggested positive safety outcomes. For example, 
Tzannatos and Kokotos (2009) and Kokotos (2013) found that ISM implementation led to a continuous and statistically significant decrease in the rates of accidents induced by human error in Greek fleet. More recently Pantouvakis and Karakasnaki (2016; 2018) found that top management commitment was positively related to ISM implementation effectiveness which in turn enhanced customer satisfaction and financial performances of shipping companies. By contrast, studies taking qualitative approaches revealed various problems associated with ISM implementation, including reluctance to report safety deficiencies (Bhattacharya 2011; 2012; Lappalainen et al. 2011; Xue et al.2018; 2019), excessive paperwork and bureaucratisation (Bhattacharya 2012; Bhattacharya and Tang 2013b; Størkersen et al. 2017), and the existence of a blame culture and distrust between the management and the crew (Bhattacharya 2012; Sampson et al. 2016; Sampson et al. 2019). This body of qualitative research further indicated that in practice managers took a behaviour-based safety management approach (Bhattacharya 2011; 2012: Walters and Bailey 2013). Taken together these two sets of findings reveal two inter-related points. First, the safe place approach as encouraged by the ISM Code has not been effectively established yet in the industry. Second, to reap more benefits of ISM implementation there are still underlying barriers to overcome.

Unlike other industries, the shipping industry is characterised by physical separation between shore-based management and shipboard workplace, and the physical distance between the shipboard workplace and shore-based management may aggravate the problem of distrust between seafarers and shore-based management. 
However, ship managers or superintendents also carry out occasional ship visit when their ships are berthed at port. According to the ISM Code, shipping companies should conduct safety audit on board ships at least once in twelve months to ensure that the SMS functions properly. Such visits establish face-to-face interaction between ship managers and seafarers. Though far from frequent, they are critical moments for POS, because only on these occasions are ship managers and superintendents able to observe real situations on board, provide guidance and support accordingly, and show their considerations for crew members and safety at workplace. This article focuses on these moments and examines managers' safety management activities during their ship visits and seafarers' responses. It serves to reveal hidden barriers to effective safety management in shipping.

\section{Research methods}

The study was conducted in two Chinese chemical shipping companies between 2009 and 2010. Both companies are headquartered in the Yangtze Delta Region in East China where the institution of the fieldwork researcher is located. As the fieldtrip involved sailing on ships (see below for detail), it was difficult to find shipping companies willing to take the trouble. Thankfully, this two shipping companies have good relationships with the fieldwork researcher's institution. With detailed explanation and the help of President of the researcher's institution, the two companies kindly agreed to take part in the study. They do not represent the whole shipping industry. Nevertheless, because tanker ships, particularly chemical tankers, can cause 
serious marine pollution and environmental damage if accidents happen, they are subject to more stringent external inspections and thus have a better safety record as compared with dry bulk and general cargo carriers (Bhattacharya and Tang 2013; Xue et al. 2018). Therefore, it can be argued that chemical tanker shipping companies pay more attention to and invest more resources in safety management. If there are lapses in their safety management, these lapses are likely to exist in other shipping sectors where there is less pressure for good safety management.

The two companies share similar features in terms of their fleets, crew teams and trade patterns. Each company operated about 20 chemical tankers and most of them sail between ports in China and those in countries around the West Asia Pacific region. Both companies were managed by Chinese managers and their ships were manned by Chinese crews. In general, the shore management of both companies were able to visit ships in ports in China at several months' intervals.

The study focused on shore management as well as crew members in the two companies. The first stage of the study was carried out in the offices of the two companies. Semi-structured interviews were conducted with 14 managers and superintendents (Their ranks and sea qualifications were illustrated in Table 1). The second stage of the study was conducted with crew members while the fieldwork researcher sailed on four ships for four voyages, two ships from each company respectively. In total, the researcher spent 45 days on ships, and conducted 55 semistructured interviews with crew members of all ranks. The interviewees basically covered a typical hierarchical structure of a ship, as shown in Figure 1. Interview 
questions were categorized into different topic areas that were related to implementation of the ISM Code. Of particular relevance to this article were management's safety inspection on board ships, its outcomes and impacts on the crew and shipboard safety practices. During the sailing voyages, the field researcher also had informal talks with crew members, observed their routine work practices as well as took field notes. These activities helped the researcher establish rapport with the interviewees and gain a good understanding of safety management on ships. The interviews were initially conducted in Chinese, but were transcribed into English at a later stage by the researcher. For ethical reasons, neither company names nor ship names nor individual names were mentioned. All the data were coded with the aid of Nvivo software. The codes were further categorized and a tree structure diagram was produced to visualise the relationships among codes and categories.

Table 1: Shore-based management interviewees

\begin{tabular}{c|c}
\hline Company 1 & Company 2 \\
\hline Vice General Manager (Safety) & Vice General Manager (Safety) \\
\hline Maritime Affairs Manager & Safety and Quality Manager \\
\hline Maritime Affairs Superintendent & Maritime Affairs Manager \\
\hline Marine Engineering Manager & Maritime Affairs Superintendent \\
\hline Marine Engineering Superintendent & Marine Engineering Manager \\
\hline Quality and Safety Superintendent & Marine Engineering Superintendent \\
\hline Crewing Vice Manager & Crewing Vice Manager \\
\hline
\end{tabular}

Figure 1: Typical shipboard hierarchy 


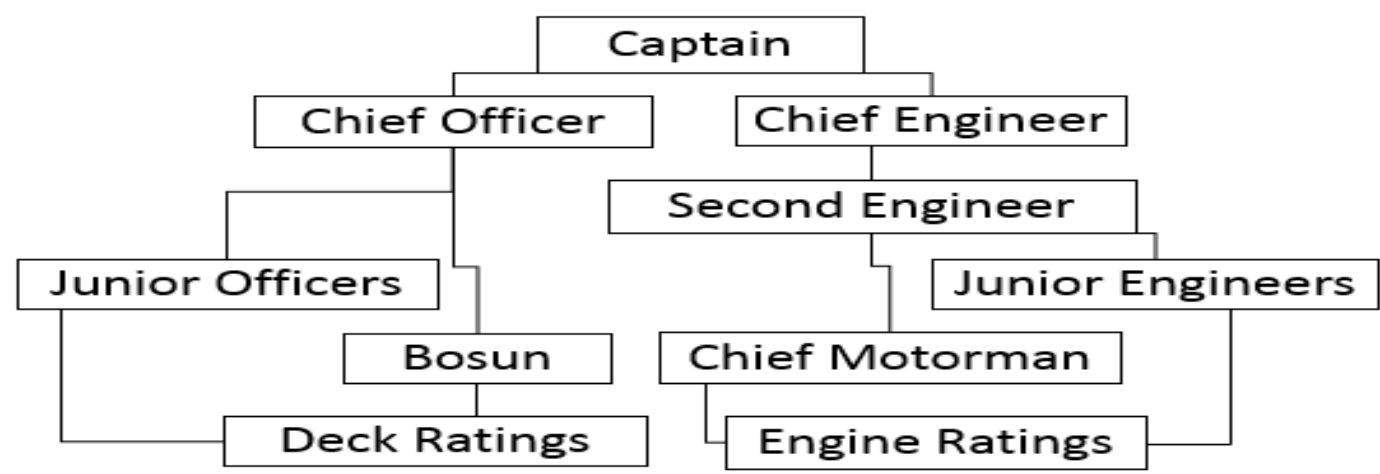

\section{Screwed focus on inspection}

The role of workplace safety tour is important in safety management of an organisation. It involves the management or their representatives routinely walking around workplace to appraise working conditions and safety practices, monitor whether safety systems function properly, identify deficiencies or areas for improvement, and make appropriate corrective actions to make things work as per the set standards and procedures. In shipping, workplace safety tour means ship visit. As required by the ISM Code, a shipping company should carry out internal safety audits on board at intervals to verify whether safety and pollution-prevention activities are carried out accordingly, and should periodically evaluate the effectiveness of the SMS in accordance with procedures established by the company.

In the two companies, ship visits were carried out by managers or superintendents responsible for the safe operation and management of ships. A visit commonly took place when one of their ships called at a domestic port, but it was also possible at a foreign port where it was necessary. There was a consensus among the management of both companies that ship visits were indispensable, and that the management was committed to shipboard safety management. 
Understandably, managers saw the physical distance between shore and ship as a significant barrier that could affect mutual communication as well as supervision. A manager expressed this common perception:

Technology-based communication has limitations. We don't work together with crew. What they say might not be the same as what they do in reality. Some of them may be very good in talking, but in practice their performance would be different to what they claimed. This is a common phenomenon. (Safety and Quality Manager, C2)

According to the requirements of the SMSs of both companies, work records should be kept on board; and on many occasions, they should also be reported to the shore management. These records serve as evidence of what and how work has been done on board. The quotation above suggest that managers did not trust such records. The managers felt that it was not sufficient for them to judge word done on board by reading reports. As such ship visits provide the opportunity to check and verify if the crew have done their work properly.

It's impossible to know the fact just from the paperwork. The role of a ship visit is prominent. The company requires the managers to visit ships regularly to judge whether the paperwork is true, or the expected outcome has been achieved. (Marine Engineering Superintendent, C2) 
These words indicate a sense of doubt. Considering the distance between shore and ship and the inability of managers to observe the shipboard workplace directly on a daily basis, such doubt is not surprising.

When managers came on board ships, they would usually carry out general inspections of the ship conditions as well as talk with some crew members. The inspections helped them check performance of the crew, and the talks enabled them to find out crew's work attitudes, as suggested by managers from both companies:

When I was on board the ship, I can understand the situation in a way which was impossible in the shore office. The crew's performance, attitudes, outcome, sense of responsibility... they all can be understood. (Quality and Safety Superintendent, C1)

When I was on board, I would try my best to talk with them (crew members) as much as possible. I could understand the situation by free chatting with them. I could obtain first-hand information through on-thespot communication. (Marine Engineering Manager, C2)

These words suggest that ship visits could be opportunities to re-establish trust as managers and the crew could communicate with each other directly as well as demonstrate what has been done and what the real situation is. Nevertheless, the first quotation also indicated that the manager focussed more on individual attitude and behaviour. Evidence below further demonstrates this. 
When visiting ships, managers also focused on teamwork on board. They understood that teamwork was one of the essential factors that could affect ship's safety. Without good teamwork, according to a marine engineering manager, 'the shipboard condition and environment would be very messy'. If it was made known to visiting managers of conflicts among some of the crew members, these conflicts would be dealt with seriously and immediately. A marine engineering manager in $\mathrm{C} 2$ presented his view on this:

Everybody is different. Some crew members were lack of a sense of responsibility. If we observe or hear that there is a conflict among them, we would solve it at earliest possible time. If we have tried and little improvement is made, we would change some of them. We would try our best to get them work together.

Apart from the concern of teamwork, individual crew members were also given concern by the management. For example, a superintendent explained:

I would talk to them individually, trying to understand whether their thoughts and mental states were stable. Otherwise, safety on board would be seriously affected. (Marine Engineering Superintendent, C1)

Another superintendent further added:

If someone had prejudice against us, his mental state would be unstable and unbalanced. This certainly would have a negative impact on his work. (Quality and Safety Superintendent, C1) 
Due to various factors, such as long-term separation from families, living in confined space, stress, fatigue, and limited shore leave, seafarers are susceptible to poor mental health (Iversen 2012). The above quotations indicate that managers were aware of this issue and this understanding made them perceive some crew as "mental unstable'. From the perspective of managers, those with 'mental issues' and those who did not have a good sense of responsibility were 'trouble makers' negatively affecting safety. One aim of ship visit was to identify 'trouble makers' and replace them if they could not be 'corrected'.

More importantly, the purpose of ship visits was to check and assess crew's work performance and outcomes. This was evidenced by the use of the word 'check' or 'inspection', which was frequently quoted during the interviews. A maritime affairs manager in $\mathrm{C} 1$ talked about his work on board:

We would check whether the crew's work conformed to the company's requirements, national and international regulations, or industrial guidelines. We would not know the situation until we had carried out an inspection. (Maritime Affairs Manager, C1)

Another manager explained why 'check' and 'inspection' were important:

Like a kid doing homework ... If we do not go to check, we could not know whether the recorded work has been completed or whether the records are correct. If the crew know that we would often check, they would make better and neater records. If they only make records without 
doing the maintenance, we would find this out by checking the equipment and know that their records are false. (Maritime Affair Manager, C2)

Again these quotations indicate a sense of doubt. Furthermore, the crew members in charge of the safety equipment were involved in the process of safety inspection, and they were usually asked to be there on spot for questions. If a problem was identified by a visiting manager, the one who was responsible for that would be required to give explanations. A marine engineering superintendent in $\mathrm{C} 2$ described a situation:

We would communicate with the crew during the inspection, letting them acknowledge that it is true they have not performed well. This plays an active role in improving their work. It is also the purpose of the management. (Marine Engineering Superintendent, C2)

In extreme cases, the crew involved could be sacked unconditionally if evidence of incompetence or lack of responsibility was identified, as was specifically mentioned by managers as well as superintendents in both companies. For example, a superintendent said:

If we found problems, we would take corresponding measures, giving criticisms or instructions or suggesting a change of personnel. (Maritime Affairs Superintendent, C2)

Overall the data suggest that during ship visits, shore managers focused on checking: checking individual attitudes and mental states, checking teamwork and relationships among crew members, and checking the outcome of the crew's work 
against the required standards. The quotations revealed a sense of distrust in accordance with previous research (Bhattacharya 2012; Sampson et al. 2016; 2019) and the word 'support' was hardly mentioned. So far, the study indicates that managers tended to take a safe person approach, with the focus and purpose of ship visits being skewed towards identifying the crew members' proper attitudes or behaviours with the hope to enforce their safety compliance. Next we turn to the crew on board ships and examine their responses to shore managers' ship visit activities.

\section{Performance appraisal and stressors}

On board the four ships in this study, one interview question was what the shore management did during their ship visits. An immediate response from many of them was 'one word: inspection', which was in consistent with what the shore managers described in the interviews. Furthermore, from the crew's perspective, one function of managers' visits and inspections was to appraise and assess their performance.

Whether you perform well or not, it's up to them (shore management); they give your performance appraisal. (Third Officer, C1)

When an inspection was complete, a ship-visit report would be produced by the visiting managers. A captain described how it worked:

The ship-visit report is clear-cut ... What does the ship's condition look like? How about the crew performance? Do they comply with the rules? Their bonus would be affected by the report. If they did not perform well, 
they could not explain or argue. Otherwise, the visiting manger could further lower their performance marks. (Captain, C2)

In $\mathrm{C} 1$, the bonus was called one-hundred-day safety bonus. In $\mathrm{C} 2$, it amounted to ten percent of a crew member's salary. If visiting managers located the problems on a ship, the responsible crew member's bonus would be deducted accordingly.

Furthermore, the inspection results could affect a crew member's prospect of promotion. In order to be promoted to a higher position, a crew member needs to have a corresponding Certificate of Competence (CoC). The Chinese Maritime Safety Administration is responsible for organising national seafarer qualification examinations regularly and issues CoCs to those who pass the corresponding examinations. In $\mathrm{C} 1$, the arrangement for crew's training and examinations was made by the managers of the company. In the understanding of the crew members, the managers tended to give priority to those whose appraisal results were satisfactory, as a second officer stated in the interview:

If you fails to do well and it is found out, this would affect management's consideration for the arrangement of your certificate-upgrading exams. It would affect your promotion. They are all relevant. (Second Officer, C1) More directly, a bad appraisal would mean no promotion even though a crew member possessed the $\mathrm{CoC}$ of a higher rank. For instance, a senior engineer gave the following reason: 
If a senior officer fails to perform well, it is impossible for him to be promoted to be a captain or chief engineer. A superintendent has the power to decide that a person could not be a captain on a ship supervised by him. (Chief Engineer, C1)

In extreme cases, as mentioned in the previous section a crew member might be dismissed by the visiting manager if evidence showed that he lacked a sense of responsibility:

Last time, when a superintendent visited the ship, a third officer was found dosed off in the cabin when he was on duty. At that time, the ship was loading cargo. He was deemed to be irresponsible and was asked to leave by the superintendent. (Bosun, C1)

Given the potential consequences, the crew members inevitably felt added pressure whenever there was a ship visit by shore management:

After all, they are the officials from the shore base. First, they will carry out inspection; second, they will conduct supervision. For us, no matter how well or badly we perform, we will have pressure. (Third Officer, C2)

A chief officer told of one occasion when his ship called at a port adjacent to his company:

It was near the company that time. The senior managers might come to visit the ship. We were very busy, to wash the deck again and again. We would definitely do the cleaning work thoroughly. The work relating to 
the hygiene in public areas or cabins had to be completed. (Chief Officer, C1)

Clearly the crew believed that it was essential to leave company's visitors a good impression of the appearance of their ship, since ship's appearance could reflect the quality of crew's work. This belief corresponded with the managers' view that good ship conditions and environment reflected good teamwork. As senior officers had more responsibilities, they bore more pressure than junior officers and ratings:

All the senior officers have immediate responsibilities over part of ship's equipment or certain types of work. When there is a ship visit, the higher the position the one has on board, the more pressure he will bear. (Second Officer, C1)

\section{Mismatched support and gaps}

As mentioned earlier, in interviews with managers regarding a ship visit, the word 'support' was rarely mentioned. The interviews with crew members suggest that the managers' ship visits did not help improve much of the crew's work. First of all, according to crew interviewees, ships were different from one another, and each ship had its own particularities. Even though a manager or superintendent worked on board before and had rich experiences, they might not be familiar with the particularities of a ship under his supervision. In this sense, it could diminish the management's supporting role, as a second engineer put it: 
Except in the case of a manager having worked on this ship before and being very familiar with this ship, otherwise, he has to listen. In practice, all the work is done by the crew on this ship. (Second Engineer, C2)

Also some senior officers with many years of sea experience thought they did not need a manager's technical support. For example, a chief engineer said:

If you expect them (managers) to solve any particular technical problems, it is impossible. Mainly, we depend on our own (skills). I have been a chief engineer for six years. It's very rare that shipboard practical problems have been solved by them. (Chief Engineer, C1)

Due to these reasons, some senior officers believed that a manager was no better than themselves in solving shipboard specific technical problems, as a second engineer stated:

For me, they (managers) are useless for helping my work. If I can solve a problem, I do not need their guidance; if I cannot, they would not be able to work it out either. (Second Engineer, C1)

The above quotations do not mean that managers cannot provide any support during their ship visits. Although they might not be able to help solve technical problems, they were in a position to provide other forms of supports. A second engineer pointed out:

We need them to coordinate work between the management office ashore and suppliers of various equipment and spare parts so that the correct 
spare parts, information and technical documents could be provided to us.

We do not have any channel to obtain them. I think this is the most helpful work for us. (Second Engineer, C1)

Among the various kinds of support that were thought helpful, arrangement of technicians for repair work, provision of safety information, and supply of materials and spare parts were highlighted by crew members. While visiting a ship, a manager or superintendent would be able to see directly what spare parts were needed and what repair work was beyond the crew's capacity but needed to be done by professional technicians ashore. The crews hoped that these could be arranged by the visiting managers.

However, the crew did not think they received such support sufficiently. For example, on a C1 ship, there was only one Ullage-Temperature-Interface (UTI) metre (A device for measuring the height and temperature of liquid cargo in a tank) on board; and on one ship of $\mathrm{C} 2$, some pipes were rusted and needed to be replaced. According to regulations as well as the SMS, a chemical tanker should carry a few UTI metres. In both cases, even though the crew reported the problems to the companies and the visiting managers also saw the situations, the ships were not provided with extra metres or new pipes for replacement. The lack of supplies caused considerable inconvenience and an additional workload to crew, as a chief engineer explained:

They (the management) want to spend less and earn more. The crew then have to work harder. A heavy workload is imposed on us. We do what we 
should do; we also have to do what we are not supposed to. (Chief engineer, $\mathrm{C} 2$ )

Thus, it can be seen that the focus of managers' ship visits was more on inspection than provision of required support. Moreover, the crew commented that this focus led to disruptions of crew's normal working rhythm, for example:

I do not expect the management's visit. If they came, my work plan would be disrupted. Then I must shift my focus to their inspections. If they see a valve plate is missing, they would ask me to fix it immediately. My view is that, first of all, I must guarantee equipment safety. For the tasks that affect little on safety, I would rather leave them aside to a later stage. But when they come, they would treat those superficial things as real problems. As a result, my work arrangement would be disrupted. (Third Engineer, C2)

Similarly, one second engineer described his experience during a ship visit: I was doing my work according to my plan. The problems could not be solved simultaneously. At that time, a manager came; he saw the workplace and asked, 'Why didn't you do this and that?' He thought my work was a mess. In fact, I was busy with maintenance on the main engine. Obviously I could not solve all the problems at the same time, but I had my own plan. At that time, my work plan was completely messed up. (Second Engineer, C1) 
Although this second engineer tried to explain the situation to the visiting superintendent, it was of little use. This was in consistent with what many of the crew members commented: visiting managers came on board to inspect and give orders, not to elicit crew's suggestions or opinions.

Because this particular focus on inspection, junior officers and ratings in particular seemed reluctant to communicate with visiting mangers. They felt that since the managers mainly came to inspect their work, it was better not to say too much in case they might said something wrong, as indicated in the following interview excerpt:

Q: Would they (managers) talk to you?

A: No.

Q: Would you hope to talk with them?

A: I don't want to chat with them to be honest.

Q: Why?

A: Sometimes, if we speak more, it is worse than if we speak less. ... There is no much common ground between us. We do more work while speak less. I feel it would be safe like this. (Chief Motorman, C2)

The above discussion suggests that from the perspective of the crew, visits from managers were more like a nuisance. Not only their working plans were disrupted but also they had to work harder to make preparations for the management's visit, which added more workload on them. Fatigue has been a well-recognised and serious problem in shipping for a long period of time (Bhattacharya and Tang 2013b; Tang and Bhattacharya 2018; Xue et al. 2017). This problem is often exacerbated during a ship's port stay by various demands on seafarers: berthing operations, cargo operations, inspections from various authorities, taking in ship supplies, and accommodating ship 
visitors including managers and superintendents (Sampson et al. 2016). In this study, the crew similarly complained that managers' visits caused lots of stress and fatigue on them. A few days before arriving at a port where a visit was planned, the crew normally tensed up and had to do more overtime work to get things ready; and when they arrived at the port, they had to accommodate the visiting managers and making corresponding corrections upon the managers' request which left them very limited time to rest. As a result, many crew members expressed their preference for 'sailing out at the seas and oceans' where they had time to relax and were able to do their work according to their routine and plan.

\section{Concluding Discussions}

To effectively manage safety in shipping, the ISM Code puts responsibilities on shipping management companies to provide shipboard employees with sufficient resources and support and to supervise the implementation of shipboard safety management. It promotes a safe place approach and encourages positive and reciprocal interaction between managers and employees.

Due to the physical distance between ships and shore-based management, occasional ship visits are good opportunities for shore managers to fulfil these responsibilities directly and to ensure good safety management on their ships. From the perspective of the crew, during ship visits, the managers were in a better position to provide support in terms of coordinating supplies of information and spare parts as well as arrangements of equipment repairs by shore-based technicians. In practice, however, 
the expectation of the crew was unmet because the managers tended to concern more about the costs rather than safety.

Furthermore, while the shore managers of both companies highly valued the opportunity of ship visits, they held a common view that if crew's performance was not assessed, they would be less likely to comply with safety rules and guidelines. From the point of view of crew members, the ship visits were characterized by safety supervision with screwed focus on crew's performance appraisal. Nevertheless, they had to respond to managers' visits in a way as expected by managers because their bonus, promotion, and even jobs were likely to be affected. This reflected a safe person approach and ship visits were used to examine the behaviours and attitudes of the crew.

As managers only visited ships occasionally rather than routinely, they might not have a sound knowledge of the visited ships or be aware of work routine on ships. By contrast, it is pointed out that crew members have an intimate knowledge of their workplace and its potential safety issues and also have the most direct interests in safeguarding workplace safety (Bhattacharya and Tang 2013a, 2013b; Gunningham 2008). In this study, apparently, visiting managers largely disregarded the knowledge and opinions of crew members when issuing orders and establishing control over shipboard work practices. They relied on their own judgements based on what they saw and what they believed while leaving limited room for seeking or listening to what the crew members thought or suggested the way the management should follow. One obvious consequence was that junior crew members tried to avoid communicating with the managers. The other consequence was more serious for safety management - by 
issuing instructions, visiting managers interrupted crew's work plans and led to extra workload, pressure, and fatigue, which was the very antithesis to safety management.

From the perspective of organisational support theory (Eisenberger et al. 1986; Eisenberger et al. 2016; Hofmann and Morgeson; 1999; Kurtessis et al. 2017; Mearns and Reader 2008), positive POS begets reciprocal upwards communication, and vice versa. In this study, the crew felt stress instead of support in their interaction with visiting managers. As a consequence, junior crew members were reluctant to make constructive communication with the visiting managers and ship visits were not properly justified to be essential and necessary in their views and largely regarded as a nuisance by the crew.

The evidence thus suggests that ship managers did not take the advantage of ship visits to fulfil their responsibilities to provide the crew with sufficient resources and support and to monitor the implementation of shipboard safety management. Instead of taking a safe place approach and fostering positive employee-manager exchange as suggested by organisational support theory, the visiting managers took a safe person approach, focussing on identifying and punishing 'bad performers' and 'trouble makers'.

As the shipping industry is characterised by physical distance between shore-based management and shipboard workplace, the distance means that ship managers may not be able to develop an adequate knowledge of specific shipboard workplace. In this context, a safe person approach not only serves to block employee participation but also results in arbitrary interventions which in turn lead to unsafe work practices. This latter 
point unveils the unintended effects that can be caused by the safe person approach. It also implicitly brings to the surface the benefit of employee participation in safety management - if the managers encouraged explanations and suggestions from crew members, probably they would develop a better understanding of the situations and make fewer interventions. Although this article only focuses on two Chinese shipping companies, this insight about unintended effects is relevant to the whole shipping industry including the offshore oil and gas sector.

Given that effective ISM implementation can enhance competitiveness and financial performances of shipping companies (Pantouvakis and Karakasnaki 2016; 2018), the practical implications of this study is also industry-wide: as ship visits are critical occasions in nurturing POS, ship managers should use these opportunities more to seek suggestions from the crew and to find out what support is genuinely necessary for safe operation of their ships. Monitoring is indispensable, but when non-compliance is identified, the focus needs to be on finding out why it occurred rather than blaming or punishing individuals.

\section{References}

Bhattacharya S (2009) The Impact of the ISM Code on the Management of Occupational Health and Safety in the Maritime Industry. PhD thesis, Cardiff University.

Bhattacharya S (2011) Sociological factors influencing the practice of incident reporting: The case of the shipping industry. Employee Relations 34(1):4-21.

Bhattacharya S (2012) The effectiveness of the ISM Code: A qualitative enquiry. Marine Policy 36(2):528-535.

Bhattacharya S and Tang L (2013a) Middle managers' role in safeguarding OHS: The case of the shipping industry. Safety Science 51(1): 63-68.

Bhattacharya S and Tang L (2013b) Fatigued for safety? Supply chain occupational health and safety initiatives in shipping. Economic and Industrial 
Democracy 34(3): 383-399.

Blau P M (1964). Exchange \& Power in Social Life. New York: Wiley.

Clarke S and Ward K (2006) The role of leader influence tactics and safety climate in engaging employee safety participation. Risk Analysis 26(5): 1175-1185.

Eisenberger R et al. (1986) Perceived Organisational Support. Journal of Applied Psychology 71(3):500-507.

Eisenberger R, Malone GP and Presson WD (2016) Optimizing perceived organizational support to enhance employee engagement. Society for Human Resource Management and Society for Industrial and Organizational Psychology. Available at: www.shrm.org/hr-today/trends-and-forecasting/special-reports-andexpert-views/Documents/SHRM-

SIOP\%20Perceived\%20Organizational\%20Support.pdf

Ellis N Bloor M and Sampson H (2010) Patterns of seafarer injuries. Maritime Policy \& Management 37(2):121-128.

Frick K and Wren J (2000) Reviewing Occupational Health and Safety Management Multiple roots, diverse perspectives and ambiguous outcomes. In: Frick K, Jensen PL, Quinlan M, et al. (eds) Systematic Occupational Health and Safety Management: Perspectives on an International Development. Amsterdam and New York: Pergamon, pp. 17-42.

Gouldner A W (1960) The norm of reciprocity: A preliminary statement. American Sociological Review, 25: 161-178.

Gunningham N (2008) Occupation Health and Safety, worker participation and the mining industry in a changing world of work. Economic and Industrial Democracy 29(3): 336-361.

Gunningham N and Johnstone R (2000) The legal construction of OHS management systems. In: Frick K, Jensen PL, Quinlan M, et al. (eds) Systematic Occupational Health and Safety Management: Perspectives on an International Development. Amsterdam and New York: Pergamon, pp. 125-148.

Hassel M, Asbjornslett BE and Hole LP (2011) Underreporting of maritime accidents to vessel accident databases. Accident Analysis \& Prevention 43(6):2053-2063.

Hofmann DA and Morgeson FP (1999) Safety-related behavior as a social exchange: The role of perceived organizational support and leader-member exchange. Journal of Applied Psychology 84(2): 286-296.

Inness M, Turner N, Barling J and Stride CB (2010) Transformational leadership and employee safety performance: A within-person, between-jobs design. Journal of Occupational Health Psychology 15(3): 279-290.

Iversen R (2012) The mental health of seafarers. International Maritime Health 63: 7879.

Kokotos DX (2013) A study of shipping accidents validates the effectiveness of ISMCode. European Scientific Journal 9(19):387-392.

Kurtessis JN, Eisenberger R, Ford MT, Buffardi LC, Stewart KA, and Adis CS (2017) Perceived organizational support: A meta-analytic evaluation of organizational support theory. Journal of Management 43(6):1854-1884.

Lappalainen J, Vepsalainen A, Salmi K and Tapaninen U (2011) Incident reporting in 
Finnish shipping companies. WMU Journal of Maritime Affairs 10(2):167-181.

Levinson H (1965) Reciprocation: The relationship between man and organization. Administrative Science Quarterly 9: 370-390.

Luo M and Shin SH (2019) Half-century research developments in maritime accidents: Future directions. Accident Analysis and Prevention 123: 448-460.

Mearns KJ and Reader T (2008) Organisational support and safety outcomes: An uninvestigated relationship? Safety Science 46(3):388-397.

Neal A, Griffin MA and Hart PM (2000) The impact of organizational climate on safety climate and individual behavior. Safety Science 34(1-3):99-109.

O'Donnell M, Ananda K L, Jayawardana A K L and Jayakody J A S K (2012) Organisational support and employee commitment in Sri Lanka. The Economic and Labour Relations Review 23(1): 125-142

Oltedal HA and McArthur DP (2011) Reporting practices in merchant shipping, and the identification of influencing factors. Safety Science 49(2):331-338.

Pantouvakis A and Karakasnaki M (2016) An empirical assessment of ISM Code effectiveness on performance: The role of ISO certification. Maritime Policy \& Management 43(7):874-886.

Pantouvakis A and Karakasnaki M (2018) The human talent and its role in ISM Code effectiveness and competitiveness in the shipping industry. Maritime Policy \& Management 2018(2):1-16.

Psarros G, Skjong R and Eide MS (2010) Under-reporting of maritime accidents. Accident Analysis \& Prevention 42(2):619-625.

Reason J (2000) Human error: models and management. British Medical Journal 320(7237):768-770.

Sampson H, Acejo I, Ellis N, Tang L, and Turgo N (2016) The relationships between seafarers and shore-side personnel: An outline report based on research undertaken in the period 2012-2016. Available at: www.sirc.cf.ac.uk/Uploads/Publications/The\%20relationships\%20between $\% 20$ s eafarers\%20and\%20shore-side\%20personnel.pdf

Sampson H, Turgo N, Acejo I, Ellis N, and Tang L (2019) 'Between a Rock and a Hard Place': The Implications of Lost Autonomy and Trust for Professionals at Sea. Work, Employment and Society, DOI: 10.1177/0950017018821284.

Tang L and Bhattacharya S (2018). Beyond the management-employee dyad: supply chain initiatives in shipping. Industrial Relations Journal 49(3): 196-210.

Tzannatos E and Kokotos D (2009) Analysis of accidents in Greek shipping during the pre-and post-ISM period. Marine Policy 33(4):679-684.

Walters D and Bailey N (2013) Lives in peril: Profit or safety in the global maritime industry? Basingstoke: PALGRAVE MACMILLAN.

Wokutch RE and VanSandt CV (2000) OHS Management in the United States and Japan: The DuPont and the Toyota Models. In: Frick K, Jensen PL, Quinlan M, et al. (eds) Systematic Occupational Health and Safety Management: Perspectives on an International Development. Amsterdam and New York: Pergamon, pp. 367387.

Xue C, Tang L, and Walters D (2017) Who is dominant? Occupational Health and 
Safety management in Chinese shipping. Journal of Industrial Relations 59(1):6584.

Xue C, Tang L, and Walters D (2018) Decoupled implementation? Incident reporting in Chinese shipping. Economic and Industrial Democracy, DOI: $0143831 X 18758175$.

Xue C, Tang L, and Walters D (2019) Occupational health and safety indicators and under-reporting: Case studies in Chinese shipping. Relations industrielles/Industrial Relations 74(1): 141-161.

Zohar D (2010) Thirty years of safety climate research: reflections and future directions. Accident Analysis and Prevention 42: 1517-1522. 